\title{
US Policy Dilemma: Food Aid to an "Enemy State"? The Case of Communist China, 1961-1963, and North Korea, 1993-2000 ${ }^{*}$
}

\author{
JEAN S. KANG**
}

Both Communist China of the early 1960s and North Korea of the 1990s posed significant policy challenges to the United States revolving around the important question of food aid. The Clinton administration was faced with the task of responding to the height of the North Korean famine, which was estimated to have taken place between 1995-1998. Interestingly, the dilemma that confronted the Clinton administration of whetlet to provide US food assistance to a nation considered an "enemy stace" was reminiscent of the circumstances faced by the Kennedy administration with regard to the famine that scoured Communise China in the early 1960s. Estimated to have daimed nearly 30 million lives, the details of the Chinese famine resulting from the Creat Leap Iorward of 1958 have only recently been examined, as foreigners were unable to gain access to the PRC until nearly twenty years after the events. Similarly, only time will bring to surface the details of the famine in Verth Kora (Demecratic People's Republic of Korea, hereafer "DPRK") due to the country's present self-imposed isolation, comparable to that of the PRC in the 1960 s.

This study will examine the policy dilemma that confronted the United States with regard to the famine ir Communisc China lollowing the cireat Leap Forwars in the 1200s and again in North Korea from 1993-2000. The divergent responses of the Kennedy administration and that of the Clinton administration will be studied, with a focus on Congressional discussions regarding the donation of US food aid to an "enemy state."

Keyunds: fond aid, famine, US-China relations, CS-North Korea relations, US Northeast Asia policy

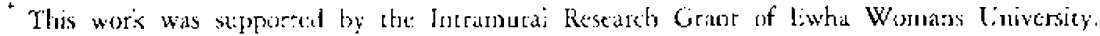

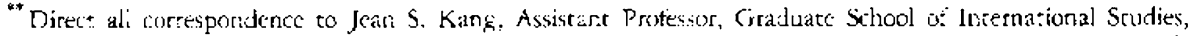
Ewha Wornars Ciniversic: 11-1 Daehyun-dong, Scociamun-gu, Scoul, i20.?50, Korea; Tel:

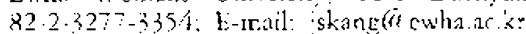




\section{INTRODUCTION}

7 he famine that ravaged North Korea will later be documented in history as one of the greacest human tragedies of the $1990 \mathrm{~s}$. Often refersed to as the "sccrct famine," widespread food shortages and starvation afflicted the entire North Korean population, yet due to restricted access into the Democratic People's Republic of Korea (DPRK), death rates and casualties cannot be verified to this day. Nonetheless, through refugee accounts and the work of religious and relief organications, the death toll is generally estimated to have been between two to three million, though thete are also other studies that suggest a lower number of casualtics.' The inability to gain access to the hermetically sealed country of North Korcal posed one of the greatest challenges to the international communitys responsc to the faminc.

The Clinton administration was faced with the task of responding to the height of the North Korean famine, which was estimated to have takcn place between 1995 and 1998. Interestingly, the dilcmma that confronted the Clinton administration of whether to provide LS food assistance to a nation considered an "enemy state" was reminiscent of the circumstances faced by the Kennedy administration with regard to the famine that scoured Communist China in the early 1960s. Estimated to have clained nearly thirty million lives, the details of the Chinese famine resulting from the Great Ieap Forward of 1958 have only recently been examined due to rhe inability of foreigners to gain access to the People's Repulblic of China (PRC) until nearly twonty years after the cvents. Similarly, only tinc will bring to surface the details of the famine in North Korea due to the prescnt sclf-imposed isolation of the state, comparable to that of the PRC. in the 1960s.

Both Communist China of the early 1960s and North Korea of the 1990 s posed policy challenges to the United States revolving around the important question of food aid. Ior the Kennedy administration, the events related to Communist China were directly influenced by the dynamics of a bipolar Cold War environment, within which the political power of the Communist bloc led by the Sovict Union was perceived domestically as being roughly equivalent to that of the United States, thereby heightening the significance of each interaction between the rwo spheres. Likewise, despite the demise of the Cold War and the rise of the IIS to glotal preeminence, many in the mid-1990s, continued to view the DPRK in the bipolar framework of the Cold War confrontation. North Korea has and continues to remain one of the last bastions of Stalinism, retaining one of the largest standing armies in the world. Thus, although in different time periods, both the People's Republic of China and the DPRK represented an "enemy state" to the United States, and the US policy response to both fanines was undoubtedly influenced by such historical circumstances. Despite the similarities in initial sccnarios, however, the US response to the North Korean famine was markedly different from its reaction in the carly $1960 \mathrm{~s}$ in the case of Communist China. 
This study will examine the policy dilenuma that confronted the Linited Staces with regard to the famine in Communist China following the Great Leap Forward in the 1960s and again in North Korea from 1993-2000. The divergent responses of the Kennedy administration and that of the Clinton administration will be studied, with a focus on Congressional discussions regarding the donation of $\mathrm{US}$ fond aid to an "enemy state." As Andrew Natsios observed in his study of the North Korean famine, although documentation of what occurred in the DPRK will continuc to be clarified and supplemented by de-classificd materials, the striking similarities between the scerarios of Communist China in the 1960 s and North Korea in the 1990 s and the US policy debates with regard to the widespread famines of these two socialist states warrant an initial study of comparison.?

\section{THE KENNEDY ADMINISTRATION AND COMMUNIST CHINA: $1961-1963$}

\section{US Policy for the People's Republic of China}

The international protile of the People's Republic of China in the 1960s was directly influenced by the political position taksn by the United States. Since October 1949, as the Chinese Communists came to power after the defeat of the Chinese Nationalists (KMT), the Truman and Fisenhower administrations had established and strictly adthered to policies of non-recognition and containment coupled with a total cmbargo against the nexily-found People's Republic. Within the context of the Cold W/ar that prevailed through the 1950s, it was established that the Unitcd Srates would focus on cortaining the spread of communism as manifested by the Peking regime and taking responsibility for the defense of the "free" Chirkese Nationalists in Taiwan.

As indicated in Rosemary Ioot's argument, the US policy of containment also implied that Waslington would make sure to adopt a policy "that did not further cmpowcr but instead diminished and held back that "awakening giant" as Communist China demonstrated rapid development during the 1950s.3. The perceived threat of international communism and the hysteria of McCarthyism proved to be an all-consuming force in the LS that left its mark on the 1950s and beyond as it ravaged any move toward a rapprochement with the Chinese Communists as "a treasonable betrayal of the national interest," ultimately resulting in "the almost total paralysis of American policy in the Orient."4

Thus, when the Kennedy administration arrived at the White House in 1961, its political stance towards the PRC had to be formulated within the context of the events of the 1950s that had indlibly shaped the image of the People's Republic in the eyes of the "free world." The Korean Wat, the two offshore islands crises of 1954-1955 and 1958, and bedligerent activities in Southeast Asia wore all incidents 
through which Peking demonstrated its continued militancy and cast inte bright light the true scope of the Chinesc Communist threat to the stability of East. Asia.

\section{China in the Aftermath of the Great Leap Forward}

Yet under its blanket of stiff hostility, by the early 1960s Communist China was alteady suffering from the disastrous consequences of the Great Leap Forward, a political campaign that focused on accelerated socialization through the mobilization of the Chinese masses. With Sino-Soviet telations at a tenuous phase and the Sovict Union continuing co display increasing technological advances as exemplified by the 1957 Spurnik launching, the Great Leap Forward was precipitated by Mao 7. Dong's desite to revive the spirit of the Chinese revolution and to dernonstrate to the world that, by concentrating on the latent energies of the Chinese tuasses, Communist China could indeed achieve rapid economic development.

However, rather than bringing about economic prosperity as originally intended, the Great Leap Forward of 1958 ultinately represented the harrowing "abandonment of a balanced development strategy" as the Chinese Communists pursued an intensive drive to promore industrial output, which focused on the building of factories throughout the country to the neglect of agricultural production.' In fact, the mears of agricultural production thomselves underwent drastic change as they were assimilated into the effort to build up industrial capacity. The PRC organized Chinese peasants into massive communes whereby thousands of individual households were combined into a "self-sufficient, cconomic, social, and political unit," hence allowing for a more complete mobilization of both male and female labor by the "pooling of all household, child-raising, and cooking arrangements" which made more workers available for the industries. ${ }^{6}$ The feverish pitch that permeated Communist China in the drive to achieve unprecedented economic growth is well-characterized by the campaign slogan for the masses to "build socialism by exerting our utmost efforts and pressing ahead consistently to achieve great, faster better and more economical results."?

Despite such fervor, however, the Great Lcap Forward would bring about disastrous consequences. Although the bountiful harvest of 1958 misled the Chinese masses as they indulged in generous meals at the commune mess halls, the conomic crisis that soon followed resulted in a famine that would ultimately claim the lives of approximatcly fifteen to thirty million Chinese and would haunt the country for years to come. 8

\section{The Evidence of Famine in China}

As the Chinese Conmunist Party veiled the disastrous consequences of the Great Leap forward campaign with denials and increased isolation of the country, the extent of the tragecties resulting from the widespread famine that followed continued 
to be a source of speculation both within China and more so to foreign observers. As Jasper Becket argues in Hungry Gbosts, Maty's Secret Famine, the enormous scale of the farnine was directly influenced and perhaps exacerbated by the secrecy that had surrounded it." Journalists and researchers from around the world were denied the opportunity of capturing the extent of the famine and portraying it to the outside world, as restrictions into the mainland wore strictly imposed by the Pcking regime: "(f)rom 1960 to 1963 they restricted the movements of resident journalists and diplomats to the main cities and halted the circulation of provincial papers outside the country."!0 Thus, the highly sccretive and controlled society manipulared by the Chinese Communist Party made it virtually impossible for the international community to assess the prevailing conditions of faminc that gripped the mainland. It was not until the mid-1980s that demographers were able to examine population statistics to reveal that "at least 30 million poople had starved to death, far more than anyone, including the most militant critics of the Chinese Communist Party had ever imagined."ll

Amid the obstacles, the American press reporting from Hong Kong dicl make it widcly known that severe food shortages afflicred the Chincse mainland. By July 1959. The New' York. Times reported that the country was "plagued by widespread food shortages." 2 Once again, the actual degrec of the fond shortage remained unclear and the Chincse government persisted in denying the systcmic failure precipitated the famine. while attriburing the fond shortage mercly to inadequate distribution methods and weather-related problems.

The uncertainty surrounding the extent of the lood shortage was perpetuated by disagrcements between outspoken scholats and proponents of the press insisting that famine ravaged the Chiness: mainland whereas others denied that such conditions existed. In recrospect, Becker claims that Washington columnist Joseph Alsop had been accurace in his assessments of severe famine on the mainland, and in attributing it to the policies of Mao 7.e Dong rather than to the natural disasters which had been cited by most as the leading cause of ayricultural difficulcies in mainland China. ${ }^{3}$ The ensuing debare regarding actual conditions in Communist China, perpctuated by the discrepancies in media reports and mainland Chinesc refugee interviews from Hong Kong, created confusion not only for the general public but also for the Kunnedy administration.

\section{Divergent Opinions on Sending Food Aid to China}

With surplus food stocks bulging in lis granarics, the inevitable cquestion of whether the $\mathrm{TS}$ should offer foud to the starving Chinese people, enemy or not, was raised to the new President in his first press conference on January 25, 1961. Kennedy asserted that he did not want to make an "idle offer" to the Chinese Communists when there was no indication "direct or indirect, private or public, that they would respond favorably to any action by the United States." 14 In addition, 
he voiced concern regarding actual conditions on the mainland, as continued exports by Communist China made the nead for food questionable. To appease those who would accuse the administration of inhumanity by denying the Chinese food aid, the door was left ajar regarding ihe possibility of future American aid, as Kennedy concluded that the Linited States would recorsicler offering aid if a recuest for lood was made by the Chinese Communists.

In the eatly 1960s, the moral obligation of the Linited States to help the starving millions was emphasized by organizations and individuals in favor of US food aid to Communist China. Organizations such as the Friends Committee for National Icgislation appealed to the American tradition of showing special concern for the world's hungry. ${ }^{\text {is }}$ In a radio interview, Senator Huhert Humphrcy (D-MiN) suggested that "relief food shipments might be an effective way of letting the people of mainland China know that the American people continued to be their friends and were not enemies as pictured by their Communist Covernment." 16 Nonetheless, due to the possibility of the Peking reginc using US food aid for propaganda purposes, he suggested as an alternative to direct aid the use of an intermediary agency to deliver food to the starving Chinese. While Titles I and II of the Public Law 480 probibited ransactions with the "union of Soviet Social Republics or any of the areas dominated or controlled by the Communist regime in China," the President had the authority to make emergency grants of foxd overseas to holp victims of natuyal disasters including famine, either directly or through agencies such as the International Red Cross, regardless of the recipient country's friendliness rowards the Lnited States. 'l'hus, those in favor of US aid to Communist China encouraged donations via international relief agencies in the hope that a US offer of food could potentially counteract the intense anti-American sentiment in China and possibly be recognized by the moderates in the Peking regime as a gesture to lessen tensions with the PRC. However, it appeared undikely that Communist China would acknowledge the need for donations from the Lnited States or any relicf agency -- such an acknowledgement would be rancamount to declaring to the world the failure of its communist system.

Despite the optimism displayed by those in favor of sending food aid to the PRC, in a reevaluation of US policy in late November 1961, Walter P. McConaughy, Assistant Secretary of Far Eastern Affairs, asserted that there was litte change in conditions which would warrant a change in the US position regarcing pussiblc food aid to Communist China. In fact, McComaughy poined to further evidence that the PRC would most likely reject any US offer in the first place: shorty after Kennedy's first press conference, the Communist Chinese Red Cross rejected an approach by the league of Rol Cross Societics in Goneva; and PRC Ambassador Wang Ping-nan at the ambassadorial talks in Warsaw turned down a suggestion by US Ambassador Beam that the Chinese consider allowing privately-sent food parcels from the Unired States. 17

According to McConaughy, it was crucial that the US did not take the initiative, for a rejection by Peking to a US offer of food would place the Kennedy administration 
in an "intolerable position," that would give Communist China ample opportunity to accuse the Linired States of trying to dispose of an unwanted food surplus. Furthermore, McConaughy teminded Under Secretary of State for Hconomic Affairs, Grorge W. Ball, that the "food situation in mainland China has arisen in part because of an effort by the Communist authorities to build a major power base at forced draft for the purpose, among others, of displacing the American presence from the Far East." I8 At this juncture, the Kennedy adtninistration was not inclined to determine that the humanitarian necds in Clina outweighed these "patent disadvantages."

\section{Congressional Views of the Chinese Famine}

As carly as January 1961, the idea of using food aid as a political bargaining tool was introduced in Congress by Rep. Emilio Q. Daddario (D)-CT). It was suggested that the Lnited States donate surplus foodstuffs in exchange for the release of political prisoners held in Communist China. This would help the Peking regime not "lose face" as it would be giving something in return for food aid. 19 Nonethcless, due to the fact that even neutral agencies, such as the International Red Cross had twise been rcjected in the past by the PRC, which declared that it did not necd outside assistance, therc loomed considerable doubt as to whether Pcking would accept food assistance under even such a face-saving plan.

In the following months, in response to the humanitatian call to help focd the starving Chinese, voices within Congress made clear their desire to differentiatc between helping the Chinese people and the Chinese Communist Party. In carly March 1961, Rep. Clement Zablocki (D-WI) rejected the idea of sending food aid to the PRC due to the possibility that the grain could be used to perpetuate the rule of the Peking regime:

There are some who criticize and say that we are unwilling to assist the poor starving Chinese. I ann sure that we would be very happy to sharc our blessings, but when we see that the Communist regime in China is sending wheat out for military purposes, should we then support that regime by making up theit stortages with sur wheat? We would want to help the Chinese people, but we have no assurance that our aid would get to them. The critics say that our Government is waiting until the Chinese stretch out their hands. This is not true. We are ever willing to help the Chinese people, bue we will never aid the Mao Tse tung government.2:

With evidence that the PRC was sending quantitics of grain out of the country in order to acquire military equipment, questions arose as to the direct beneficiaries of LS food aid: the Communist military or the starving Chincse people? Evidence scemed to inclicate that the former was more likely to reap the bulk of the benefits and this possibility was further highlighted by the fact that the Peking regime 
would not allow the CS to verify the recipients of food aid. The inability to monitor the path of donated food grains posed a scrious obstacle to the idca of sending food aid to Communist China.

During the early months of 1961, in efforts to block potential support for Communist China's admission to the United Nations, members of Congress pointed to the insistence of the Peking regime that the enemy of the Chinese state remained the United States, thus emphasizing the visible hostility of the PRC toward the US. On May 29, 196 I Rep. Donald C. Bruce (R-IN) released for the Congressional Record an article from the Indianapnlis Star arguing that "(e)very American should firmly realize that the Red Chinese regard the Lnited States as their No.l enemy and have as their major objective to drive the Lnited States out of the Orient." 1 Not only was Communist China responsible for the growing propaganda against the Unitcd Stares found iu Japan and the military preparedness in North Korea, but more importantly, the PRC had the potential to cooperate with the Soviet Union based on the two Communist states' mutual feelings of enmity against the US. It was warned in Congress that the PRC "is a dedicated and aggressive Communist power cnjoying the full support and cooperation of Soviet Russia and openly, daily, and loudly broadcasting its hate for the Linited Staces." 22

A statement by Senator Frank Lausche ( $\mathbf{D}-\mathrm{OH}$ ) captured the growing conccons over the possible deleterious use of LS aid by the hustile Clinese state: "When we give them aid in solving their problems, we relieve them of the responsibility of growing food and we hdp them in their purpose of producing guns, possibly to be used against our American youth." 23 In a testimony hefore the Senate Judiciary Commites, the president of the Chinese Refugec Relief Committee also urged against Amcrican inclinations to send US food aid to the starving millions on the Chinese mainland, as those desiring to help the hungry by sending food to the PRC government would only "consolidate the power of Red China in denying freedom to its pcople." 24 It was further claimed that "Communist army guards are well ted, well clothed, and well armed," which added to the lasting images of US food aid potentially helping maintain the well-bxing of the Chinese Communist military rather than the people. Thus, humanitarian instincts were to a certian extent suppressed in Congress by the overriding possibility of American fous aid being used by the Peking regine to develop and sustain its military that was posed inimically against the United States.

\section{THE CLINTON ADMINISTRATION AND NORTH KOREA: 1993-2000}

\section{US Policy for North Korea}

'The LS policy dilemma regarding food aid ro North Korea in the 1990 s was 
similar to that regarding the PRC in the 1960s. However, the responses of the respertive US adtuinistrations were profoundly different. In the case of North Korea, since the end of the Korean War in 1953, the main abjective of the United States has been to deres further North Korean aggression. Hence, since 1994, the relationship) between North Korea and the United Stares revolved primarily around the DPRK's nuckear and ballistic weapons program and the resulting security concerns posed to the Linited States and its intcrests in Northeast Asia.

In 1994, upon evidence that the North Korean government had covertly developed a ruckear weapons program and possessed enough plutonium tor at least two nuckar weapous at a site in Yonglyon, the Linited States, Japan, and South Korea attempted to convince the DPRK to relinguish the facility and to terminate its nuclear program. After scveral months of negotiations, the US effort to halt the development of nuclcar weaponry in North Korea finally reaped substanive success as the Lrited Statcs and North Korea conceded to an arrangernent known as the Agreed Framework, signed on October 21, 199.4. The bilareral agreement focused on the eventual resolution of the muclear issue and has as its ultimate objective the peace and security of a nuclear-free Korcan peninsula.

In early December 1994, Robert Manning, a former senior State Department official on Asian affairs, pointed out in his testimony that the agreement with the Nurth Koreans was indeed an attempt "to accommodate them, bring them into the community of nations, enginetr a kind of soft landing, if you will, and a gradual reunification process." 25 Incleed, the Clintun idministration took a fundamentally different stance towated the "enemy state" from that of the Kennedy administration, as it chose to engage the DPRK towards cooperation through the Agreed Framework, rather than pursuing the alternatives of further isolation of the hermetic nation or possible confrontation. Thus, the decision of whether to send LS food aid to North Korea was atso couched in terms of attempting to accomruodate the wcakened state, rather than to confront or to promotc its firther demise.

\section{A Regime in Crisis}

The early 1990s had ushered in an cra of crisis for the state of North Korea. The demise of the Soviet Union and subsequent breakdown of the Cold War led to drastic reductions in subsidized food, oil, and equipment to Noth Korea from its former patrons, China and the Soviet Union, which directly impacted the agricultural and industrial uucput of the North Korean regime. As extcrnal trade reached its lowest levels in history, the massive decline in the profuction of goods and poor harests, coupled with successive floods and droughts, precipitated the plummeting of the North Korean economy. 26 It was becoming increasingly clear that Norch Korea neither had the adequate resources to feed its population nor the necessary fueds to purchase needed provisions from other countries. 
Meanwhile, during this time of crisis, North Korea was widely perceived by the international community as one of the most reclusive, inaccessible, and highly controlled police states. For the past thircy years, North Korea has pursued a state policy of extreme self-reliance, $j u b$ be, which mandates strict adherence to a uniquely socialist approach to political, economic, and social policies dictated by the statc. Yet, "Iespite the illusion of self-sufficiency, or juche, the North is increasingly dependent on ourside help to sustain itself."2? Since its inception following the Korean War, North Korea had in fact been heavily dependent upon subsidized oil, grain, machinery, and military equipment from both the former. Soviet linion and China, in ironic contrast to the juche theory propagated by the regime. However, while North Korea's imports from the Sovier Union totaled more than US\$1.7 billion annually between 1987 and1990, they fell to less than US\$ 600 million, in 1991, and by 1993, the figure was a mere one-tench of the products coming from the Sovict Linion during 1987-1990.?8 By 1993-1994, China's own natural conditions had worsened to the point that China stopped subsidizing oil to North Korea and placed a ban on the exports of rice, corn and soyheans. ${ }^{29}$

Thus, with exterail trade plummeting, the shortages of food, energy, and raw matcrials within North Korea had reached crisis proportions by the mid-1990s. By 1994, the isolated state was short a half million tons of grain and, furthermore, lacked the necessary hard currency to purchase needed foodstuffs from the international market. When the harvest was discovered to be $33 \%$ short of the necessary food to feed its population, the DPRK could find neither the requisite hard currency nor the effective political ties that could provide the much-necded assistance.

\section{Evidence of Faminc in North Korea}

Despite North Korean attempts to disguise the extent of the food shortages, the United States and South Korea had acquired intelligence information as early as 1993 that verified suspicions of acute shortages of food. In January 1994, prompted by evidence of a covert North Korean nuclear weapons program, two US senaturs visited South Korea and released a detailed report of their findings. The report outlined the increasingly debilitating conditions in North Korea and highlighted the spiraling number of North Korcans attempting to cross over into China to escape dire circumstances surrounding the food crisis. ${ }^{30}$

Although North Korea hesitatingly allowed a sclected group of humanitarian aid officials access into the country (unlike the PRC of the 1960s, which allowed very few forcigners into its territory during the time of its rampant faminc), the actual conditions afflicting the North Korcan masses werc nonetheless difficult to unveil. The governing ideology of the state prevented Pyongyang from accurate disclosure of the prevailing circumstances of the country and scifled effurts by various aid agcncies in the necessary monitoring and distribution of much-needed food.

The regime's efforts were clearly causing discrepancics in on-site rcports by relicf 
workers and resulted in an overall debate on the exact conditions prevailing in North Korea. Contrary to what tumanitarian aid officials cxpected to sec in North Korca, reports by various reliet agrencies told of conditions that were nowhere near crisis proportions. There appeared to be fear signs suggesting acute food shortages, to the extent that some relief officials wondered whether famine existed at all in North Korea. In fact, numerous reports coming from obsenvers within the country "adamantly rejected the idea that the courtry as a whole was facing mass starvation." 3 i 'The litemational Foderation of the Red Cross and Red Crescent Societies estimated that only 130,000 people were starving and several hundred in need out of the total. puputation of twenty-three million.

Meanwhile, information regarding widespread famino and devastating social conditions in North Korea surtaced through refugee accounts from those who had crossed into China to escape the ravages of acure food shortages and also from the yrowing number of defectors into South Korea. Interviews with scveral hundred refugees at the North Korean-Chinese border, which did not begin until mid-1997, nearly two years after North Korea's request for international aid, revealed a picture of the DPRK which contrasted vastly from the reports of humanitarian aid workers who were in-residence in Pyongyang. ${ }^{2}-$ Refugees told of a country rith mass starvation, where people werc sulfering from severe malnutrition due to the lack of food. 3.3 The discrepancies between reports from the humanitarian aid community and personal accounts of the hundreds of refugees and defectors from the country fueled intense dehate worldwide regarding the gcouine situation in North Korea.

\section{The Recpuest for Food Aid}

Unlike Communist China in the 1960 s, North Korea did make a formal request. for fond to the United States as early as 1994 during nogotiations related to the DPRK's nuclear program. After the floods during the summer of 1995 destroyed nearly three million cons of emergency grain reserves, it was estimated that nearly 5.2 million out of a population of approximately twenty-three million were alfected and that several hundreds of thousands were left homeless. 34 Thus, against strong inclinations to disguise the extent of damage in order to uphold its juble idcology, the severity of the foxd cmergency forced the North Korean government to appeal to the international community for assistance.

Despite the DPRK's request, however, significant international aid was not offered to North Korca until late 1996. The UN World Food Programme's October 5 , 1995 appeal for $4 \$ \$ 8.8$ million in foud to help cover the anticipated shortages due to the extensive flooding was largely ignored by the international community. It was not until the Washington Post highlighted the lack of international aid given to the UN World Food Programme (WTP) in a December 1995 report that the international society recognized the potential severity of the North Korean situation. Thus, when severe floods hit North Korea again in the summer of 1996, the 
country was once again devastated as an cstimated US\$1.7 billion in damages to the harvests and infrastructure left ncarly 2.5 million women and children "at serious risk of starvation." is

\section{The US Response to Food Aid}

In spite of early indications that scvere food shortages existed in North Korea, the United States did not react to the brewing crisis until October 1995. The initial North Korean request for a million metric tons (M'1) of food aid in 1994 was unequivocally rejected by the United Stares, the decision bcing based on Public Law $480.5 \%$ However, in response to the UN World Food Programme's worldwide appeal for L:S\$8.8 million in aid to the DPRK, the United States pledged US\$25,000 to the United Nations children's agency, UNICEF, and an additional US $\$ 200,000$ to the UN Department of Humanitarian Affairs (DHA) in 1995. Considered to be relatively insignificant, token amounts of aid, the Clinton administration indicated that US aid was limited due to resistance from Republican congressional members who opposed any form of aid to North Korea. Senators, including many Democrats, rcmained skeptical of the US ability to ensure proper enforcement of the Agreed Framework. One of the most outspoken proponents against LS involvernerit with North Korea, Senate Majority Leader Bob Dole (R-KS), openly criticized the Clinton administration for negotiating any deal with North Korea as it would be "propping up an odious regime that is closer to full collapse than at any time in the past forty years." "is Hence, the Clinton ardministration's policy of engaging the reclusive DPRK faced substantial congressional opposition from the very outset.

In late January 1996, the United States, South Korea, and Japan held high-level discussions regarding the future course of action to take regarding the North Korean food crisis. While both the South Korean and Japanese governments opposed further aid on the basis that circumstances of famine were being exaggerated by the North Korean government and by claims that food aid was being diverted to feed the DPRK's military, the United States, believing that aid was an effective inducement to lead North Korca towards peace talks and discussions of peninsular security, proposed to provide LS\$2 million in US fuod aicl, and in February 1906, proceeded to donate US\$2 millien to the WFP's Octoher 1995 appeal. 9 A $\Lambda$ U policy of engagement was distinctly encrging. Assistant Secretary of State Winston Lord claimed that US aid was a "symbolic, humanitarian grestlire" in response to the dire circumstances confronted by the North Korean people. In In this way, the (linton administration launched itself on a signilicantly different path toward dealing with a possible "enemy state" than that taken by the Kennedy government.

\section{The Policicization of Foud Aid}

Food aid becanc a political tool to be utilized by both the US and the DPRK 
in theis rrutual course of improving relations. In April 1996, President Clinton and South Korcan President Kim Young Sam initiated a proposal inviting the North Korean government to participate in peace ealks involving the United States, North and Sourh Kortas, and China. Anticiparing North Korearn resistance, US food aid was disectly linked to the DPRK's participation at these tailks, signaling the clear politicization of food aid. In the summer of 1996. Charles Kartman, the principal Depury Assistane Secretary of State for East Asian and Pacitic Atfater, indicated to UN officials that negotiations with North Korea regarding its participation at che four-parcy calks revolved aruene' the issue of food and il Esscncially. if North Korea agreed to participate in the four-party talks and progress was visibice, the DPRK would reccive LIS foed aid. This linkage of food air! to the belavior of the IDPRK demonstrated that lumantarian considerations were only pare of the basis for the granting of humanitarian aid

On the other hand, months later in Sepecmber, North Korca denonirtated its continued stance as a "rogiele" statc in an inseccessful espionage mission which provoled international cutrage ans adversely affected future fond aid commitments by both the United States and South Korea. As a North Korean submarine ran aground onto South Korear; torritory, the inciclent represented the I)PRK's continued intransigence. despite its need o: international food aid. As part of the heates: response by the lis and south Korean governments, foud aid was innediatedy

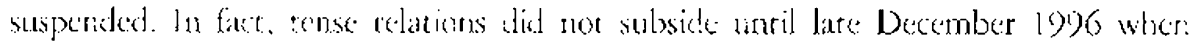

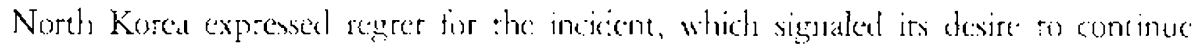
discussion of further food aik

The possibility of futhes instathility in Vorth Korea a lso prompted a response from the United States in mic-Futhary 199\%. With C.IA ant: Defense Inrelligence Agency estinsates that acute lood shortages in the DPRK could lead to a potential military coup agalinst the Kim Jong-il reginc, the linited stares confronted the possibility of a ciesperate, underted, and chaotic North Korea. Consequently, on Hebruary 19. 19)7 the Inited States pledgred 27.000 M'] of prajer to a recent WhI $T^{r}$ ispecal. Secretary of State Madeleine Albrighe partially justified the increase

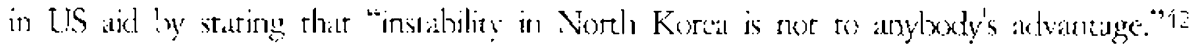

In Apr:l bos?. North Korea blatandy politicized the food aid issue by insisting that unless is received 1.5 milion rons of forod aid from the Lated States and Soutl Korea, it would rar participate in the four-party peace talks. Initially unwilling to concecie to Nurh Korca's domands, the Inited Stares and South Korea refused to accept the conditions set oy the DPRK; yet by nid-July, the Initec Seares had pledged anther $1000000 \mathrm{M} I$ of grain to the W'l'P's carly July appeal for aid. Wh White the State Depatment deried any linkage with the imnending tour-party talks scheduled o begin thee wetks later. editorials in the Wahkngion Posi stiggested thit US aid was undeniably linker e progess made towards the upcoming talks.

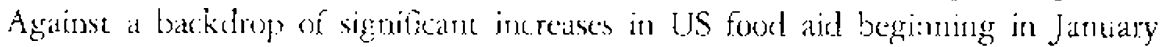
19)8 with the pledging o: $200,000 \mathrm{MT}$ of emergency humanitarian aik? from 
P.L. 480 Title 1l, North Korca launched a I'acpodong missile on August 31, 1998 over Japanese airspace, again bringing about great international condemnation. This atrempt to rest the DPRK's ballistic missile capability tepresented a direct threat to American soil, as it dcmonstrated that North Korean missiles could potentially reach the western and central regions of the Unired States. Yer despire this incident, the Clinton administration conmitted an additional 300,000 MT of grain to North Korea. Not surprisingly, the surprise launch by the DPRK and the subsequent lack of change in the administration's position again ignited the fermenting opposition against further LS aid to North Korea. The incident was considered an "egregious affront" which prompted the possibility of terminating US aid to North Korca indefinitely.

\section{Heightened Criticism in Congress}

The Taepodong missilc launching opened up room for more compelling and aggressive Congressional opposition against the increase of US food aid to North Korea. Opposition to furcher aid was heightened as suspicions arose in Washington due to unexplained construction in North Kurea. The White House produced aerial photographs suggesting the development of massive tunnels that intelligence analysts suspected to be a new facility for the production of nuclear weapons. To many members of Congress, sulstantial evidence that North Korea had resumed its building of nuclear weapons would prove Pyongyang's violation of the $\Lambda$ greed Framework, which would ultimatrely provide ample justification for the temination of food aid. Yet, annic these suspicions, the launching of the Taepodong missile, and accumulating opposition to the government's policy, the IJS on September 21,1998 responded tinhesitatingly to a WFP appeal by pledging 300,000 MT of foos assistance ${ }^{4}$

Despite the linwavering stance of the Clinton administration, the Congressional response to the recent events was to capitalize on the cumulated evidence of the DPRK's continued belligerent posture vis-à-vis the outside world in order to lautich a more effective opposition campaign. Republican Congressman Christopher Cox (R-CA) titilized the negative sentiments of recent events to propose an anendment to the foreign affairs budget that would stop all US government food aid to the DPRK. It was insisted that food assistance was being diverted to the North Korcan military, "the apparatus of repression that keeps Kim Jong Il in power." 4 > Furthermore, Cox suggested that the Clinton administration was in fact responding to nuclear: blackmail by North Korea, and demanded closer monitoring of aid distribution as a prercquisite to any future considerations of aid.

Congressman Benjamin Gilman (R-A Y), chairman of the House International Relations Committee and a key signatory of the congressional ketter to the Clinton administration condemning the US policy approach to North Korea, also dispatched a bipartisan tcam of congressional staffers to investigate the status of the famine 
and the impact of food assistance in the DPRK. ${ }^{2}$ If the findings confinmed congressional suspicions of aid being diverted to those other than the intended recipients, If aid would mose likely be terminated.

\section{The Commissioning of a Policy Review on North Korea}

The Clinton administration responded to increasing congressional criticism by appointing former Defense Secretary William J. Perry as a special coordinator on issues related to the DPRK. The North Korca policy review tcam, commissioned in November 1998 to conduct a comprehensive revicw of US policy toward North Korea, was an atempe by the Clinton atoministration to enhane the legitimacy of US policy regarding the DPRK.

Yet, as the North Korean government again linked politics with food aid in mid-November 1998 by demanding increased aid in return for allowing IIS officials to inspect the underground construction of a suspected new nuclear facility at Kumchangri, the congressional response was to seize the opportunity to highlight the DPRK's continucd hostility and suggest the need for the Clinton administration to alter its policy direction. ${ }^{47}$ Despite increasing congressional outrage, the Clinton administration was able to reach an agreement with North Korea to allow US inspection of the Kumchangri muclear facility. It was later announced, however, that just days prior to the reaching of the agreement, the United States had pledged 100,000 MT of grain to a recent WTP appeal that could only be perceived as the inducement for North Korean cooperation.

Soon thereaftet, Congressman Benjamin Gilman asserced that the LS responsc of providing increased food assistance, in effect, represented a "food for access" deal. In a $N_{w} w$ York Times article. former US Secretary of State James $\Lambda$. Baker also criticized the tradeotf made by the linited States vis-à-vis the DPRK, warning that "North Koreans may well conclude that their bad behavior will continue to be rewarded." 18 Unwavering in the face of escalating criticism, on March 22. 1999 the Clinton administration announced that the United States would donate US\$30 million to the WTP for an additional 100,000 MT of corn and rice to help sill the shortall in the WIP's latest appeal. The clain that the Clinton administration was running a "fon! for access" deal was further reinforced as the Department of Agriculture announced the additional supply of $400,000 \mathrm{MT}$ of foud aid one day prior to the arrival of $L S$ inspectors in North Korea. Agriculture Secrecary Dan Glickman, however, explained the large-scalc commitment as a means to help alleviate the growing grain surplus while engaging in a humanitarian gesture tuwards North Korea. Meanwhile. North Korea publicly announced through its foreign ministry that the US-North Korea agreement regardistg the inspection of sites at Kunchangri had been established based on the DPRK's belict that the US "should properly compensare as in order to end their suspicions."49

Critics of Clintoris policies roward North Korca condemed what appeased ro 
be a massive payoff by the Llaited States to gain acess for inspection of the suspected nuckar facility. Nonctheless, US inspecors arrived in Pyongyang on Maly 18, 1949 - amid reports from Scoul cmphasizing that it was unlikely that any evidence of a nuclear weapons program would be found at the Kumchangri site. In fact, a senior researcher at the Korean Institute of National Unification asserted, "The cave is vacant. There's nothing there. It's only a bargaining chip for the North." "Wu With this in minc, Republican Congressman Benjamin Gilman led the opposition in voicing pointed criticism to a deal that would remain as an unconfortable precedent for tucure US-Nortl Korca negotiatons:

'like Kunhangei visit is not the success story the Administration has bern playing it up to lx:. T:x mat for a visit to Kumbiangri is acrually a fisilure of North Korea to keep irs end of the Agreed Franework. The significance of this event is further diminished by the $\$ 180$ million in food aid the United States save to North korca tor cuntrance to this sure to be timpty faciliry. Are we going to have to cough up $\$ 200$ million every tame we frod a suspicious Verth Korea sitc that may violate the Agresed Frannework? The Agreed Franework is no model of modern arms control anc: we are sure to pass this way again with Pyongyang. The ruestion is whit will the price he rext tinis?

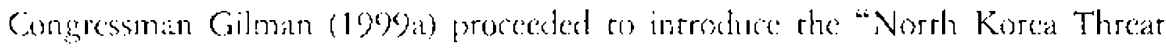
Reduction. Act of 1999," which was supported by other opponents of the Clinen administration's policies roward Vorth Korea. As it pertained to food aid, the bill focused on the "fulfillonent of conditions desinned to ensure that foos is now diverted to the North Koran military and that North Korea is taking steps to regain self-stifficiency in food production." Gilman in his subsequent address at the Asia Soctety stiggested that the Clinton administration had become the DPRK's "main betefactor" dirough large aikl packages elcspite the fake that North Korea was "the county most likely at this poini to involse the Unitud States

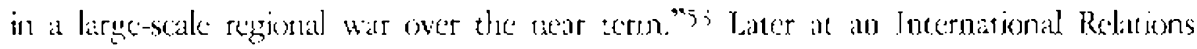
Commires hearing, Comeressman Gilman accused the Clinem ardministration of engaging the Initce: Stirces in a "successfu. cycle of political hackmail and extortion" while the DPRK contiand to develop milistic missice capable of reaching the Inited States. it

\section{9. 'The Perry Repurt: Continued Engagement and Aid}

In liglst of mounting opposition, on September 15, 1999 former Secretary of Defonse William J. Perry met with members of Congress to present his report un LS policy toward the DPRK. ${ }^{55}$ Although most of the Pexry Repost remained 
classified, his message to Congress highlighted his overall view ehat the United States should cugage in a "comprethensive and integrated approach" toward the DPRK, ultimately resulting in the establishment of diflomatic relations with North Korea. Two days later, the White House announced that the Clinton administration. influenced by Pcrry's recommendations as well as by recent US-North Korean negotiations, wuuld ease several sanctions against the IPPRK administered under the Trading With the Encmy Act, Detconse Production Act, and the Department of Commerce's Export Administration Kegulations, with the purpose of improving overall relations with No:th Korea under the Agreed Framework.jor

In fact. the Perry Report signaled the beginnings of an increasingly recoptive posture to improved relations by both the United States and North Korea. With disclision of a potential visie by a top, Nortl Korcan official to Washington and the possible visit by Secterary of State Mateline Albrighr to North Korea, the Clinton administration's policies of engagement scemed to be bearing fout is rerns of having the rogue state comply with the terms of the Agrced Framework and participate ia che tour-party talks. As the Clinton administrarior continued to purst: "constructive cialogue" with the DPRK, Washingron moved to "provide some immediate and tangible support" tor the inter-Korcar. summit by pledging as additional $50,0030 \mathrm{MT}$ of $\mathrm{grain}$ to the W'P on June 15,2000 , ;ust days after the talks commenced in North Korea." Athough Washington continued to deny links of L'S food aid to political developments, it was announced by the State Department that the Cinited States expected to finish providing by the cand of June 2000 the 400,000 MT of foot shiprnents pledgect to the WTP in July of the previous ycar.

As . North Korea displayed "a pateen of hehavior" that signaled the DPRK's desire to join the international com:nunity, the Clineon administration pursued a duai "carrot and stick" approach toward North Korca. On the one hand, the Linited States continued to p'an a national anti-missice defense system to gratord against potential IPPRK missie covelopment, while on the other it fostered further improvements in North Korea's pesture vis-à-vis the international community. Among the advocases for national wissile defense, Scrator Dick Durbin (D-IL) arguted that the DPRK represenced the "tanmy du jour" and that the Linited States necded to take recessary preciutions as a moans of maintaming national security. On the other hand, in favor of continuing engagement with the DPRK. Senator John Kerry (D-MA) argued that "ithe threat from rogue missile programs is neither as imminent not as immutable as sume have argued. We have time to lise the diplomatic tonls at our dispusal to try to alecr the pulitical calculation a rogue nation. will make hefore it decides to use its ballistic missile capability. "5s

In the month price to the LS presidential elecrions, the visit of the Vice Chairman of the DPRK's National Defense Commission, Clo Myong-nok, to Washington arkl IIS Secretary of State Madeleine Albright's sojourn to Nowh Korea represented the zenith in a serits of murual efforts to butcher improve relations between the 
United States and the DPRK. Despite outstanding issues related to military matters, the first high-level visit by a North Korean official to Washington indicated to observers the DPRK's desire to further enlance relations with the United States before a ncw administration came to office. Sccretary of State Madeleine Albright's October 23, 2000 visit to Pyongyang to meet with DPRK leader Kim Jong-il represented the final coustesy by the Clinton administration before leaving office, demonstrationg US willingness to interact with North Korea in an attempt to bring the DPRK into the community of nations. During the Albright visit to North Korea, the DPRK country director for the World Food Programme, Douglas Broderick, stated that US food aid had played an important part in the movement toward possible rapprochement between the United States and Nurth Korca. Broderick asserted that "(c)he food aid has opened the doxr. It has established trust."59 'Thus, food aid, usced as a political tool, had effectively functioned as the mediator between the USS and an "trieny state." However, edespite the progress made in relations between rite United States and the DPRK, the suscainability of improved relations remained in question as uncercainty loomed regarding the next administration's approach to the IDPRK.

\section{CONCLUSION}

'The Kenmedy and Clinton administrations confronted remarkably similar scenarios with respect to the widespread famines in the socialist states of China and North Korcid -- both were faced with rhe policy dilemma of providing humanitarian aid to acrively belligerent "enemy states" amid heavy Congressional opposition. Upon examination of their responses to these situations, however, significant differences can be found resulting from the contrasting nature of the security framework of the US at the time and the actitude of the "enemy state" in question for each administration.

Though it appeared that Kennedy was interested in the idea of using food as a means to promote change in Sino-Amcrican relations, potentially destructive political ramifications ultimately led the administration to withdraw from its offer of aid to Communist China. Whereas the PRC's obstinare refusal to acknowledge its failure by accepting aid and continued thrcats of domestic reprisal from Congress and the China Lobby constituted ample justification for the Kennedy administration to suspend possible advances toward mainland China, the most destructive factor militating against a change in Sino-American relations was the increasingly belligerent posture assumed by Pcking, evidenced by continucd meddling in Southeast Asia and ultimately in China's attack on the northeast border of India in Octoher 1962. Convinced that the Peking regine was not interested in joining the international community in peace, the Kennedy administration eventually acquiesced to domestic pressure to deny Anetican food aid to Communist China. 
Neverthcless, through the discussion of possible US food aid to the Chinese mainland in the early $1960 \mathrm{~s}$, it was reinforced that the Linited States could not dismiss Communist China as mercly a temporary irritant in its forcign policy. In fact, policymakers recognized that the United States would incvitably be forced to interact with the Peking regime, and thus, some relentlessly continued to advise more flexibility in US policy toward China. Kennedy, at one of his last press conferences on November 14, 1963. clearly left the door ajar regarding future Sino-American relations as he declased that the United States was not "wedded to a policy of hostility to Red China," and that when the latter indicated a desirc to live at peace with other countrics, the LS would reappraise its policies coward Communist Clina. ${ }^{60}$ Hence, improvement in Sino-Arracrican relations always remained a possibjlity, although it was not attained during the Kennedy administration.

In the discussion of food assistance ro North Korea during the Clinton admirtistration, Congressional opposition to providing IS aid repeatedly placed emphasis on the threat posed by the DPRK to its neighboring nations, due to the nuclear and ballistic missile developments as well as the belligerenc behavior exhibired by North Kurca. Despite the demise of the Cold War, for those opponents who had adamantly opposed the Clinton administration's attempts to engage North Korea, the Cold War context still prevailed on the Korean peninsula. 'Therefore, the offering of US aid was equated with "feeding the enenyy" a concept that prevailed over the Kentedy administration's decision regarding food aid for Communist China during the 1960 s.

Interestingly, however, the Inited States in this casc fulfilled the position of heing one of the largest domors of aid to North Korea despire its continued status as an "enemy state" of the LS, a contradiction which can largely be attributed to the engagement policy of the Clineon administrarion. However, as the Clinton administration's term came to an end. US policy toward the DPRK remained precarious. Despite progress made toward improved relations between the Linited States and North Korea, there was no doubt that the DPRK still retained its status as one of the last remaining "enemy states" from the Cold War. In view of the potential threat posed by North Korea, not only to the Korean peninsula, but to surrounding nations such as Japan, as well as to the United States and its allics ar large, the perplexing gucstion of how to best deal with the rogue state was left to the incoming Goorge W. Bush aldministration.

Similar to the case of widespread famine in Communist China during the 1960 s, the lack of sufficient data and the corrinued impenetrability of the North Korcan state make it impossible to verify how many dicd as a result of the widespread food shortages in the mid-1990s, when the famine was suspecied to be at its height. Nonctheless, the opportunity to respond to North Korea's requests for food assistarce allowed the Clinton administration to pursue a posture that was decidedly differetat from Kennedy's decision to deny food aid to Communist China. As to the long-term effects of following such a different policy course vis-à-vis 
an "enemy state," it should be noted that they can only be determined well after history has taken its course.

\section{REFFRENCES}

Acheson, Dean. 1958. Pmier and Diplomay. Cambridgs: Harvard Liniversicy Press. 1969). Present at the Creation. New York: Norton.

Armstrong, Charles K. 1998. 'A Socialism of our Style': Nurth Kurcan ideology in a Post-Communist Era. In Nortis Kirrem Forign Relations in the Past-Cald Wat Era, ed. Samuel S. Kim. New York: Oxford Lnversicy Press.

Arnold, David. 1988. Famines: Social Crisis and Hitmitat Change. Oxford: Basil Blackwell.

Bachrack, Stanley D. 1976. The Committee of Ome Million: "Chima Lobsy:" Politios, 1953 1971. New York: Columbia Universiry Press.

Baker, James A. 199). North Korea Wins Again. The New York Times via Noritktit Aria Peare and Sechity Netumk Dail) Rapon (March 19).

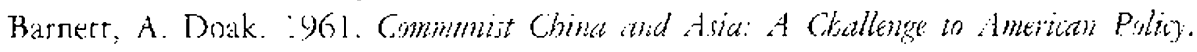
New York: Vintage. Insticurion. 19:7. Chiac snd the Matro Pnurs in Asia. Washington, D.C.: Brookings

Becker, Jasper. 1996; 1998. Huniry Ghabli Mao's Serret Famine. New York: Free Press; Henry Ifolt.

Blum, Robert. 1966. The Grited States and Chima in World Affinin. Now York: McGin-Hill.

1966. L.S. Polisy Towards Communist China - The Aletnatives.

The Healline Series No. 180 (December), ed. A. Daak Banett. Foreign Policy Association.

Bowles, Chester A. 1960. The 'China Problem' Recunsidered. Fortigh Afjains (April). York: Harper \& Row.

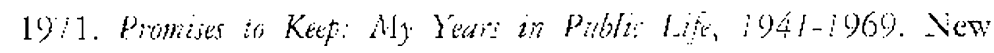

Bracken, Paul. 1995. Nuclear Weapons and State Survival in Vorch Konad. Sarnat 35(3) (Autuma): 137-53.

Bunge. Frederica M. 1981. Nonth Kone: A Commy Stmb, Washington, D.C.: Foreign Area Stucies, American University.

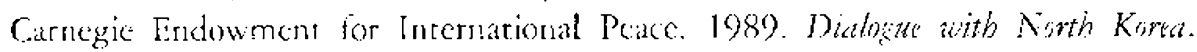
Washington, D.C.: Carnegie Endowment for Intcrnatioral Peace.

Chang, Crordon, H. 1900. Frimendi and Fiemies. Stanford: Stanford liniversity Press. Chang, Hsin-hai 1965. Amema and China: A New Apmoh to Asia. New York: Simun and Schuster.

Cohen, Jerome A., et al., eds. 197:. Tainan and Anertion Foregh Palig: The Dilomm in U.S.-China Relations. New Yorix: Pracger. 


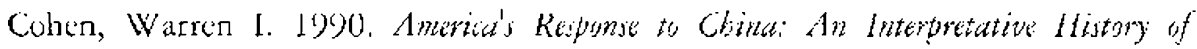
Sinte-Amerian Relations. 3rd ed. New York: Wiley.

19)3. The Cambritge Hintmy of Amerian Fortign Relations. Cambridge (England); New York: Cambridge University Press.

Congressional Quarterly Service, ed. 1967. China and L.S. Far Eat Polity, 1945-1967. W ashington, D.C.

Cumings, Bruce. 1997. Korea's Place in the Sun: A Midem Histon. New York: W. W. Notton.

Cuny, Frederick C. and Richard Hill. 1999. Famine, Contlict and Responte: A Baisc Gridc. West liartford, Conn.: Kumarian Press.

Dean Rolect 1). 1998. Masculinity as Kecology: John F. Kennedy and the Domestic Politics of Forcign Policy. Diplonatic listsy 22 (1).

Deuchler, Marrina. 1992. The Confurian Tranjommation of Korua: A Sudy of Sociely and henlogr. Cambridge, Mass: Council on East Asian Studies, Harvard L, nuversity Press.

[Diamond, Johr. 2000). For North Korea, IIS. Offers Carrot, Stick. Chicag' Tributhe

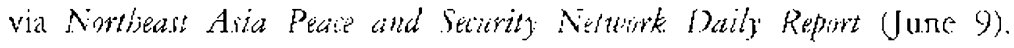

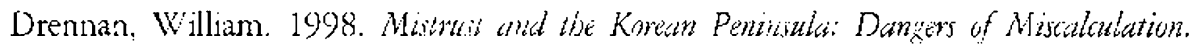
Special Riport. Washington, D.C.: L'nited States Institute of Peace.

Dulles, Foster 'Thea. 1972. Americin Pijlig Toward Commuist China, 1949-1969. New York: Crowel'.

Eberstadt, Vicjolas. 1992; i993. Can the Iwo Korca Bo One. Figreign Affairs (Winter): $150-65$.

1995. Kunt Apmothes Rumificution. Armonk, N.Y.: M.E.Sharpe.

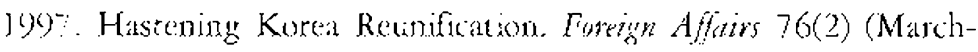
Aprily: $7 ?-92$.

Institute:

Eberstadt, Nicholas, Marc Rubin, and Albina Tretyakova, 1995. 'I he Collapse of Sovict and Russian Trade with the DPRK, 1989-1993: Impact and Implications.

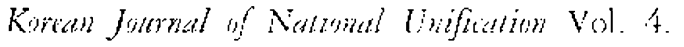

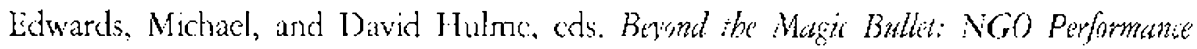

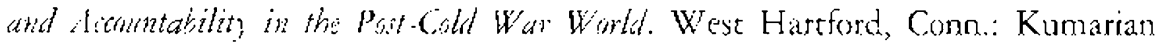
Press.

Fvans, Paul. 1998. Integrating North Korea: Roles and Dilcmmas for the International Community. Paper presented at a conference on Korea and the Search for Pcace in Northeast Asia. Ritsumeikan Liniversity, Kyoto, Japan, December 9-11.

Fairbank, John K. i967. Coind 'The Poult's Mitdle Kingtim and the U.S.A. Cambridge: llarvard Unjuersity Press. . ad. 1968. The Chinese Wold Order. Cambridge: Harvard University Press. 
1971. The United Siates and China. Cambridge: Harvard Liniversity

Press.

Fairbank, John K., Edwin O. Reischauer and Albert Craig. 1965. Last Asia: The Modern Transformation. Boston: Houghton Mifflin.

Feis, Herbert. 1953. The China Tangle. Princeton: Princeron University Press.

Feczer, James. 1989. Clinging to Containment: China Policy. Kennedy's Quest for Victory. American Foreign Polic;, $1961-1963$, ed. Thomas G. Parerson. New York: Oxford University Press.

Foot, Rosemary. 1990. 'The Search for a Modus Vivendi: Anglo-American Relations and China Policy in the Eisenhower Era. In The Great Poners in East Asia, 1953-1960, eds. Warren I. Cohen and Akira Iriye. New York: Columbia University Press. . 1995. The Pratice of Power: Lis. Relations witb Cbina Since 1949. Oxford: Clarendon Press.

Friedman, Edward and Matk Selden, eds. 1971. Americall Aika. New York: Pantheon. Gaddis, John Iewis. 1983. The Emerging Post-Revisionist Synthesis of the Origins of the Cold War. Diplmatic History (Summer).

Giacomo, Carol. 1999). Perry Briefs Congress on . North Korea Report. Reurers (September 15) via Nmtheast Liza Peaie and Security Netumk Daily Repont (September $17)$.

Gilman, Benjamin. 1999. Gilman Introduces Bipartisan North Korea Bill, Says Policy is in Need of Overhaul. U.S. House of Representatives Commitece on International Relations (May 19) via Northeast Aria Peace and Security Netuork. Daily Report (May 20).

1999. Gilman: North Korean 'Holds out One Hand for Aid While in the Other Hand It Holds a Gun." Statement of Representative Benjanin Gilman, Chairman, House International Relations Committec at a Hearing on The Misuse of U.S. Aid to Vorth Korea (Octoher 27) via the Nombeast Asia Peate and Security Network Special Repont (October 29).

Gittings, John. 1969. The Great Power Triangle and Chinese Foreign Policy. Cbina Quarerly Uuly?.

Goldman, Leonard H.D. 1985. United States Opposition to Use of Force in the Tawan Strait, 1954-1962. Joumal of American History (December).

Guhin, Michael A. 1)6\%. The United States and the Chinese People's Republic: The Non-Recognition Policy Revicwed. Intmational Affairs (January).

I an-Jackson, Sarah. 1998. American Stonewalls North's Play for Cash. Agence France-Pressc via Northeast Asia Puse rend Security Nenumk Daily Repont (December 1).

Harrison, Selig. 1997. Promoting a Soft Landing in Korca. Foreign Policy. No. 106 (Spring).

Henricksen, Thomas H. and Jongryn Mo, eds. 1997. Nonth Korea after Kim II Sung: Continuit; of Change? Stanford, Calif.: Hoover Institution Press. Hilsman, Roger. 1967. Ta None a Narion: 'The Politia of Forrion Polin; in the Administation 
of John F. Kennedy. New York: Doubleday.

Hincon, Harold, ed. 1978. Goternment and Politics in Revolutionary Cbina: Selected Documents, 1948-1979. Wilmingtion: Scholarly Resources.

Hornbeck, Stanley K. 1955. Which Chinese: Diplomatic Recognition and Official Representation. Forign Affairs (October).

Hughes, Christopher W. 1996. 'The Norch Korean Nuclear Crisis and Japanese Security. Sunival 38(2): 79-103.

Immerman, Richard H., ed. 1990. John Fouser Dulles and the Diplonacy of the Cold War, Princcton: Princeton Universicy Press.

Itiyc, Akira. 1963. Dilenmas of American Policy Toward Formosa. China Quarterly (July-Sepermber).

1967. Across the Parific. New York: Harcourt, Brace and Workd. 1968. L.S. Polio: Toward China: Testimony Taken from the Senate Foretgn

Relations Committe Hecining, i966. Boston: Iittle, Brown.

. 1974. The Cold War in Asia. Englewood Cliffs: Prentice-Hall. ,ed. 1990. The Great Pmiers in Last Asia, 1953-3960. New York:

Columbia University Press.

-1992. Cbint and Japan in the Global Setting. Cambridge: Harvard University Press.

Kautman, Burton 1. 1993. John F. Kennedy as World Leader. Diplomatic History. $17(3)$.

Keiman, Goorge F. 1266. Realines of Anerican Foreign Policy. New York: Norton. Kcsaris, Paul, ed. 1982. C1A Research Reponts: China, 1946-1976. Frederick, Md.: Microfilm.

Kim, Il Pyong J., ed. 1987. The Strategic Triangle: China, The United States and the Sotiet Union. Niw York: Paragon House.

Kim, Kook-Chin. 1997. Crisis Management on the Korean Peninsula: A Korean View. Paper presented at a conference sponsored by the Brookings lnstitution and the Institute for Forcign and National Security (IFANS). Washingeon, D.C. (July $9-10)$.

Kim, Samuel S. 1998. North Kurean Foretgn Relations in the Poxt-Cold War Era. Hong Kong: Oxford Liniversity Press.

Kirk, Donald. 1999. Dual Purpose in U.S. Trip to Pyongyang. The International Herald Tribune via Northeast Asia Peace and Security Daily Repont (May 18).

Kissinger, Henry A. 1969. American Foreign Policy. New York: W.W. Nurton \& Company.

Korcan Buddhist Sharing Movement (KBSM). 1998. 7be Ford Crisis of North Korea Winessed by Fond Refugeer. Reported in five issues (Ietoruary 23, March 23, May 23. June 23, and November 23).

. 1999. Repent on Daily Life and Human Rights of Nonth Koraan Food Refugees in China: Based an Field Sume' in 2.479 Villages in 'Three Nortbeast Siates in (bina. Scoul: KBSM (Junc). 
Kusnitc, Leonard A. 1984. Public Opinion and Forign Polio: Ambrica's Chinu Policy. 1949-1979. Westport: Greenwood.

Kunz, Diane B., ed. 1994. The Diplomacy of the Crucial Decade: Amerian Foreign Relatione During the 1960's. New York: Columbia University Press.

Kunz, Diane B. and Steven M. Gillon. 1993. American During the Cald War. Fort Worth: Harcourt Brace Jovanovich.

Kyung, Yi Sun. 1997. Inside the Hermit Kingdon: A Memoir. Toronto: Kcy Porter Books.

Lautze, Sue. 1996. Nurth Korea food Aid Assessment. Conducted for the L:S. OIDA, USAID (June).

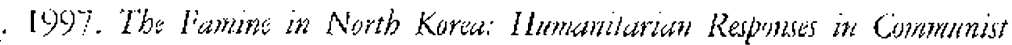
Nation. Cambridge, Mass: Feinstein International Famine Center, Tufts University (line).

Lee, Hy-Sang. 1994. Supply and Demand for Grains in North Korca: A Ilistorical Movement Model for 1966-1993. Kofed and Warld Affairi 18(3): 509-53.

Levin, Norman D. 1998. What if North Korea Survives? Suringl 39)(4): 156-74. Iewis, John W. 1962. Quemoy and America China Policy. Asict Sume; (March). Lowenthal, Richard. 1961. Diplomacy and Revolucion: 'Ihe Dialectics of a Disputc. China Quarterly (January).

MacFarquhar, Roderick. 1972. Simo-Amerian Relations. 1949-1971. New York: Pracger.

1983. The Onigin of the Cullural Retituton, Vol 2., The Crut Leap Forucurd, 1958-1960. New York: Columbia Luiversity Press.

Manning, Robert. I994. Commitee Testimony, Inplication of the Li.S. North Korean Nuclear Agrement. Hearing before the Subcommittee on East Asian and Pacific Affairs on the Committec on Foreign Relaitons, II.S. Senate (December 1). Washington, D.C.: U.S. Government Printing Office.

May, Ernest R. and James C. Thomson. 1972. Ameriam-lait Aizan Relatimn: $A$ Suncy. Cambridge: Harvard University Press.

Medecins Sass Fronticres (MSF). 1998. Vorth Korea: Testimonies of lamine, Refugec Intervicws from the Sino-Kotcan Botder. (August). New York: Doctor Without Border/ Medicins Sans Froneiceses.

Moorstein, Richard and Morton Abranuwirz. 1971. Romaking Cbina Polio: U.S.-China Relation and Gomemmental Deatsmmaking. Cambridge: Harvard Iniversity Press.

Nathanail, Tola. 1996. Fond and Nutitimal Aisessment, Democratic Penplés Repriblic of Korea (March 16-April 24) Rone: UN World Food Program.

Vatsios, 1999. The Politics of Famine in North Korea. The U.S. Inititute of Pexte Special Report (August 2). Washington, 1).C.: [I.S. Institutc of Peace Press. 2001. The Great Nonts Korean Famine: Famine, Polith, and Foreing Polic: Washiengion, D.C.: L.S. Institute of Pcace Press.

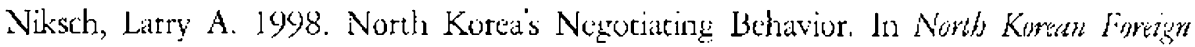
Relatimi in the Pts:-Cold War lira, ed. Samuel S. Kinn. Hong Kong: Oxford 
Iniversity Press.

Noland, Mascus. 1997. North Korea: Present Status aod Prospects for Survival to the Yoar 20000. Statement prepared for hearings by the United States Senate Committee on Forcign Rclation;, Subcommitee on East Asian and Pacific Affairs (July 8).

. 1947. Why North Korea Will Muddle Ihrough. Foreign Affais 26(4) (July-August); $105-18$.

Noland, Marcus, Sherman Robinson, and Tau Wang. 1999. Famine in North Korca: Causes and Cures. Workirger Paper 90.2. Washington, D.C.: Institute tor Internarienal Ficonomics.

1999. Rigorous Speculation: The Collapse and Revival of the North Korean Economy. Working Paper 99.1. Washington, D.C.: [nstitute for International liconomics.

Nunn, Sam and Richard Lugar. 1994. Statement on the Korcan Peninsula: Summary of Findings and Recommendations (March 3). U.S. Palicj 'Iowand North Karea. Hearing lefore the Subcommittoe on East Asian and Pacific Affais of the Committer on Furcign Relations, U.S. Scrate (March 3). Washington, D.C.: U.S. Govemment Printing Office.

Obesdurfer' 1)on. 1997. 'The Tu', Koredir: A Contemporary History. Reading, Mass.: Addisisn-Weslay.

Patk, S. Han, ed. 1996. Noth Korts: Ldedogy, Politics, and Fonomp. Englewood Cliffs, N.J.: Prenrice-Hall.

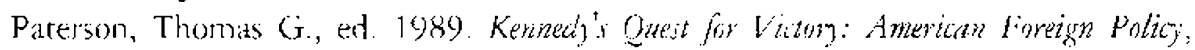
1961-1963. New Yor'x.

Quinones, C. Kenneth. 1998. North Korea: From Containment to Engagement. In Nitith Kow ajter Kim I/ Sung, ceds. Dac-Sook Sub and Chac-Jin Lee. Boulder; Colo.: Lynne Rienner.

Rankin, Karl Lo:t. 196k. Chma Assgentent. Scatele: University of Washington Press.

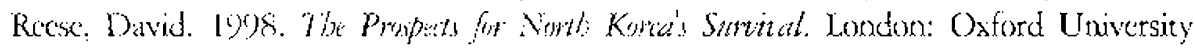
Press.

Rhodes, Chris. 1996. The Juche Idea and its Role in the North Korcan Political Economy. In Nowth Kriva in the New World Orcher, ed. Hazel Smich et al. New Yorti: St. Martin's Pross.

Rony, Denny. :997. Worth Korea as an Alienated State. Sumial 38(1) (Winter): $22-36$.

Rusk. Dean. i49(). A. I Sai It. New York: W.W. Norton.

Sanger, 1) avid. 1998. U.S. to Send Vorth Korea Food Lespite Lissile Launching. Whe Now Time (Stptember 10).

Scalapino, Robert A. 16) T. North Korca at a Crossroads. Stanford, Calif.: Hoover Institution Press, Stantord Iniversity.

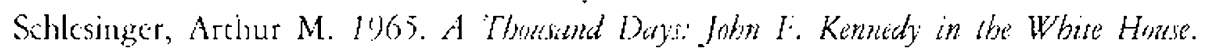
Boston: Houghton Mifitir. 
Schoenbaum, Thomas J. 1988. Waging Peace and War: Dean Rusk in the Truman, Kennedy, and Johnson Yars. New York: Simon and Schuster.

Schumann, Franz. 1971. The logic of Wirld Pruer: An Inquing int the Origins, Cumonts, and Contradictions of World Politics. Ncw York: Pantheon.

Segal, Gerald. 1985. Difending China. New York: Oxford University Press.

Shuman, Michael. 2000. Albright Iauds Steps Taken by Washington and Pyongyang.

The Asian Wall Street Journal via Nortbarst Asia Peace and Seurity Netumk Daily

Repont (October 24).

Simon, Nancy S. 1982. Irom the Chinese Civil War to the Shanghai Communique:

Changing U.S. Perceptions of China as a Security Threat. Ph.D. disscrtation, Johns Ilopkins Lniversity.

Smith, Itaccl, and et al. 1996. Narb Kore in the New World Order. New York:

St. Martin's Press.

Smith, Jeffrey R. 1996. U.S. Defied Allies, Grants $\$ 2$ Million in Humanitarian

Aid to North Korea. The Washington Pojst (February j).

Snyder Scott. 1994. North Korea's Nudear Program: Challenge and Opportunity for American Pfligy. Special Report. Washington, D.C.: United States Institute of Peace.

Washington, D.C.: United States Institutic of Peace.

1996. A Coming Cristis on the Korkan Peninsala? Special Report. 1998. Challonges of Building a Konan Psac Process: Political and Economic

Tranition in the Korcan Peninula. Special Report. Washington, D.C.: Lnited States Institute of Peace.

1999. Negotiating on the Edge: North Korean Negritiating Behavior.

Washington, D.C.: Lnited Staces Institute of Peace Press.

Spence, Jonathan. 1990. The Search for Modem China. New York: Norton.

Stevenson, Adlai. 1959. Putting First I'hings First. Frreign Affairs (Octoher).

Stolper, Thomas E. 1985. China, Taivan. and the Offsomre Islands. Armonk, M.E.: Sharpe.

Sullivan, Kevin. 1996. N. Korean 'Fannine' Debated: S. Korca, U.S., Japan Iair to Agree on Aid. The Wabington Past (January 27).

Thomson, James C., Jr. 1967. Dragon Under Glass: Time for a New China Policy. The Atlantic (October).

. 1972. On the Making of Li.S. China Policy, 1961-1969 - A Study

in Bureaucratic Politics. The China Quarterly 50 (April-June): $220-43$. - 1985. Sentimental Iniperialists: The American Experience in East Aisa.

New York: Harper and Row.

Iownsend, James R. and Brantly Womak. 1989. $\rho_{6} /$ itics in China. 3rd ed. Buston:

Litule Brown and Company.

Tucker, Nancy B. 1983. Palterns in the Dust: Chinest-American Relations and the Recognition Controzersy. New York: Columbia Iniversity Press.

1990. A House Divifed: The United States, the Deprartment of 
Statc, and China. In The Great Poners in liast Asia, 1953-1960, eds. Warren I. Cohen and Akira Iriyc. New York: Columbia University Press.

1990. John Foster Dulles and the Taiwan Roots of the "Two Chinas'

Policy. In John Foter Dulles and the Diphomag of the Cold War, ed. Richard Immerman.

Princeton: Princston Lniversity Press.

1994. Tatwain, Hons Kong, and the lintted States, 1945-1992, Incrtain

Fnicndibips. New York: Twayne.

Lnited States. Deparment of State. 1960-1963. Bulletin. Washington, D.C. 1961. Public Papers of the Presidents of the Unitad States: Jobn F. Kenmedy

1061-1963. Washington, D.C.

1996. Foreign Relaton of the linited State: Diplomatic Paters 1961-1963:

Nonlbeast Asict Vol. XXII. Washington, D.C.

World Food Program and Food and Agriculnutc Organization of the Linited Nations.

Crup and Food Supply Asiessment Mision to the Democratic Peoples Repulilic of Korea. Special Reports, issued December 1995; December 1996; November 1997; November 1998: November 1999.

Young, Kenneth. 1968. Negotiating with the Chinete Communits: The United Statis Exyerience, 1953-1967. Vew York: McGraw Hill.

\section{ENDNOTES}

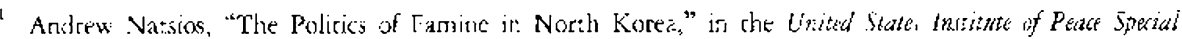

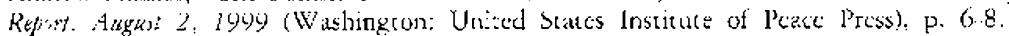

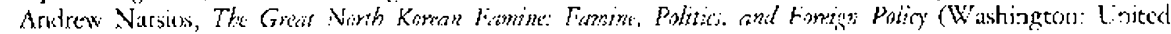
States Insti:ute of Peace Press, $2001 \%$ p. 13.

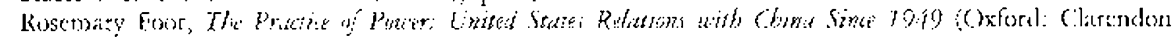
Press, :995: p. 15

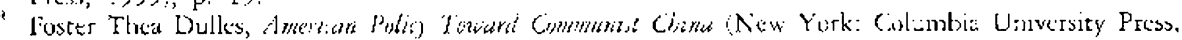
$19-2), 7$. 30 .

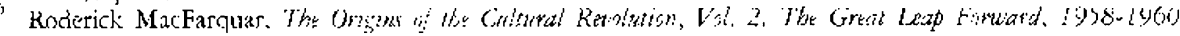
(Now Yout: Columbia In Inivessity Press, 1983): 1?. 1

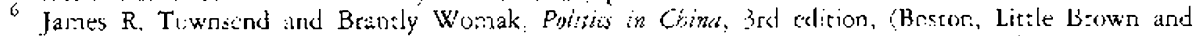

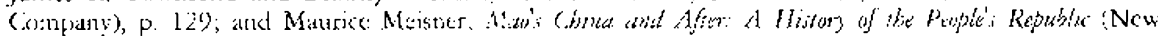
York. 'lhe Free Press, 1977 , P. 235.

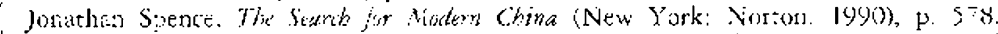

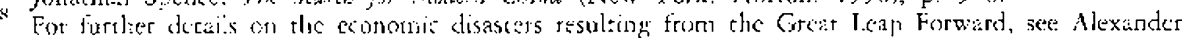

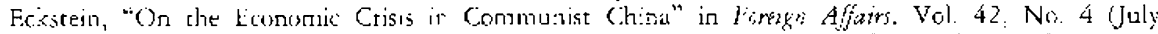

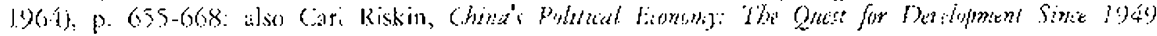
(Oxtore: (Oxiord iniversity Press: 1987).

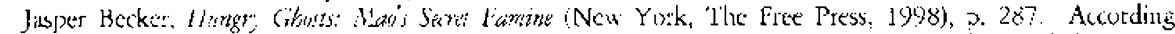

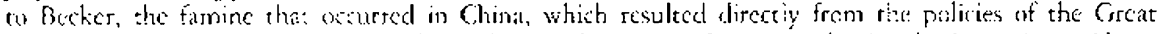

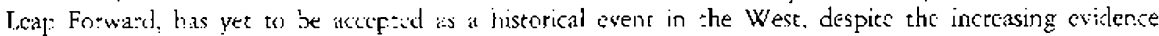

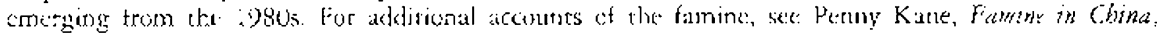

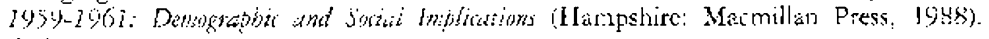

ii. Lisi, p. 29j5.

"Bccket, Whongh Ghosti, p' 24).

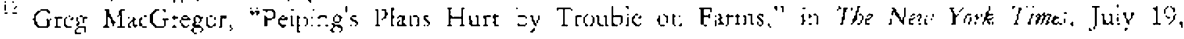
1959

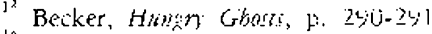

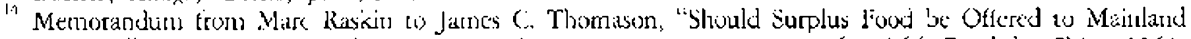

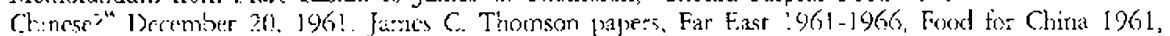




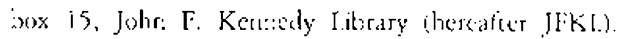

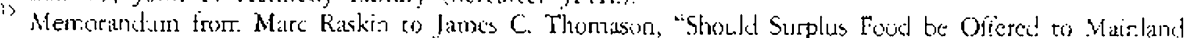

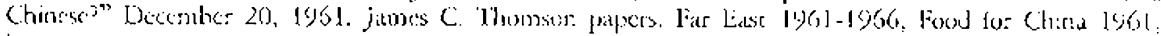
bax 15, jliKl.

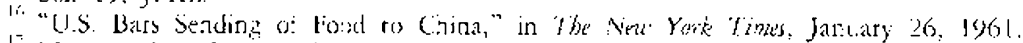

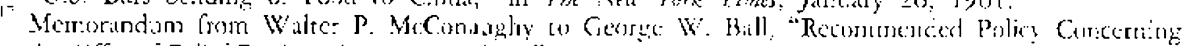

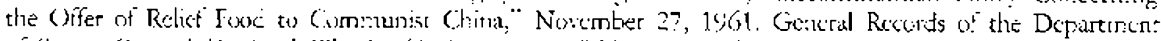

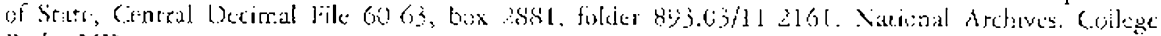
Pask, Mi).

"ltid.

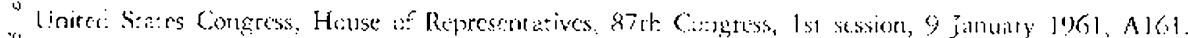

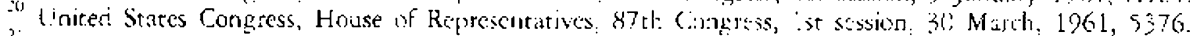

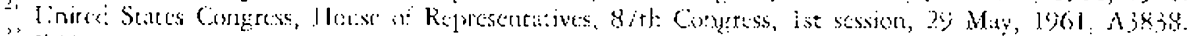

$\because$ Ibid.

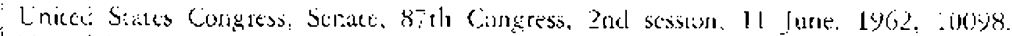

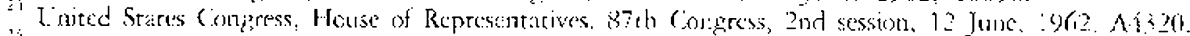

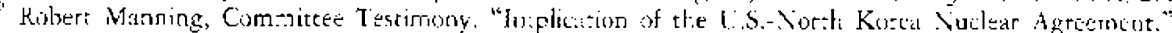

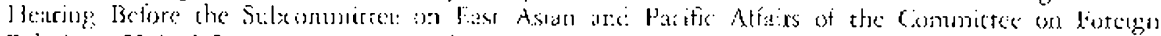

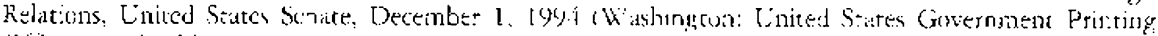
Oifkej, p. $6 \%$-rít.

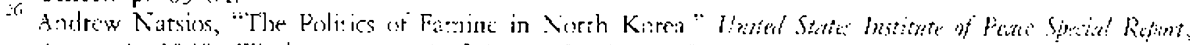

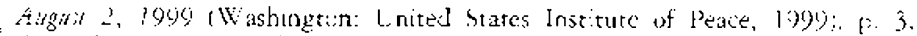

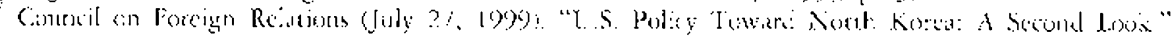

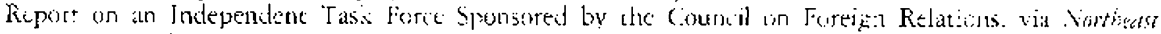

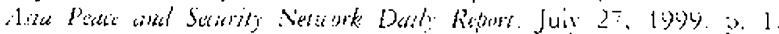

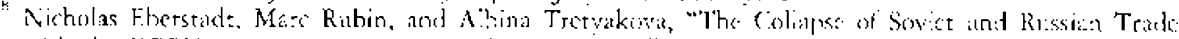

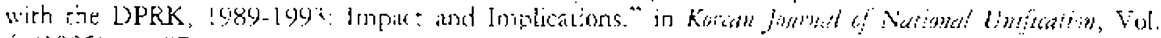
(1095). 1). (9?

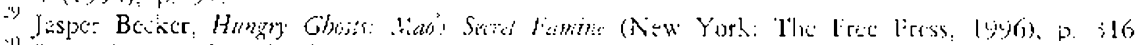

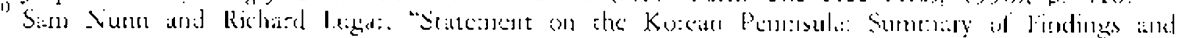

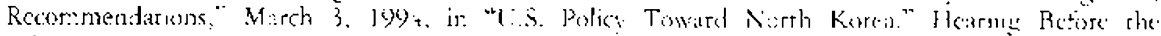

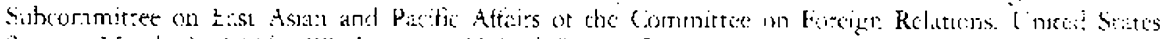

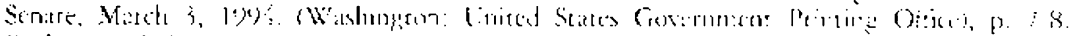
Becker, p. 31s.

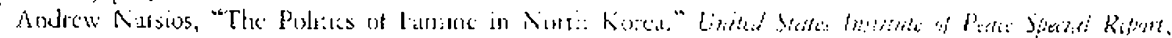

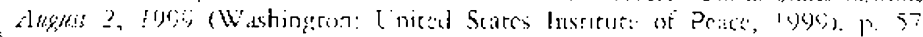

Becker, p. 32?-3?2.

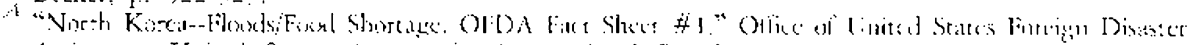

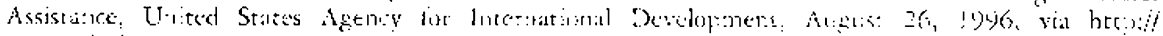
www.esliefwethont

[loid.

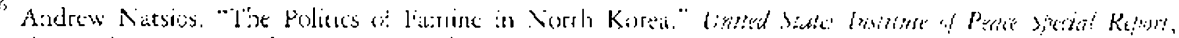

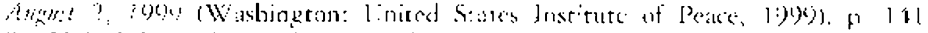

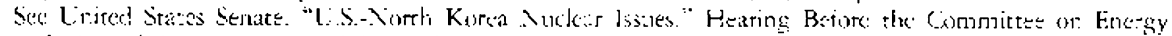

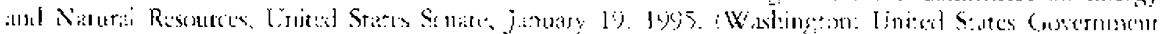

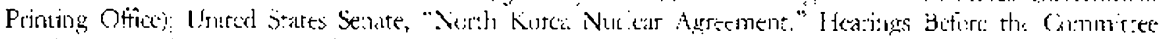

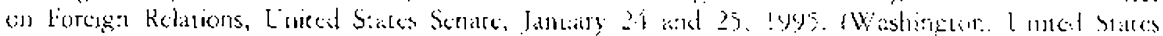
Goversment Prinuse (Mficis.

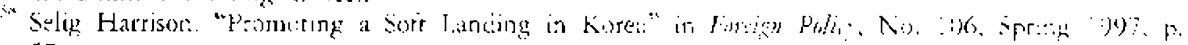
$5 ?$.

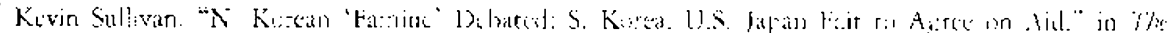

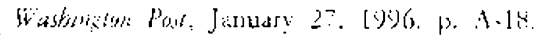

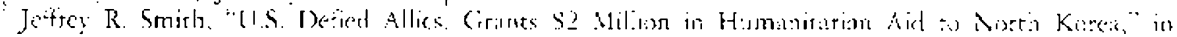

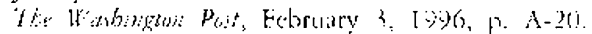

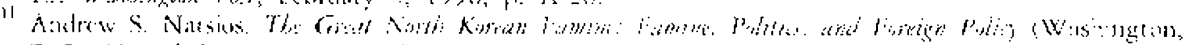

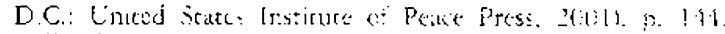

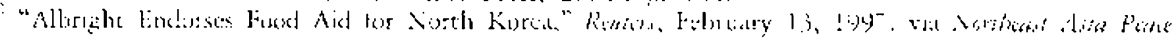

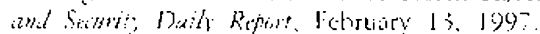

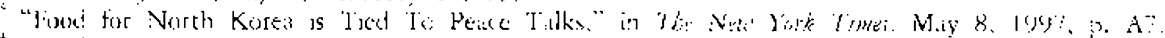

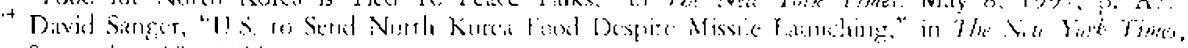
Siprenters lis, Iy)

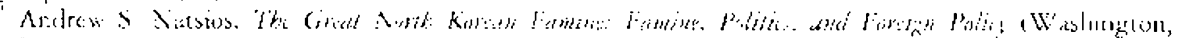

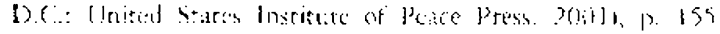


is Thic: p. 160 .

Saran Jakson-Han, "Ame:ica Sitoncwalls -Vurtis Play for Cast," Agence France-Pressc, Dectmber

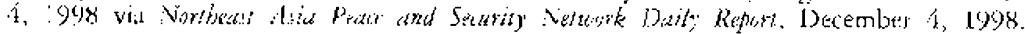

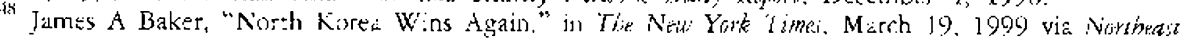

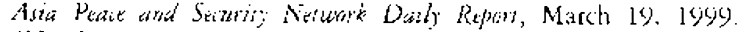

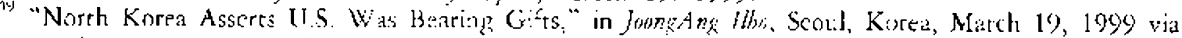

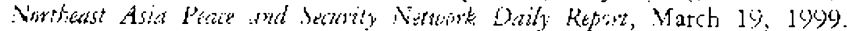

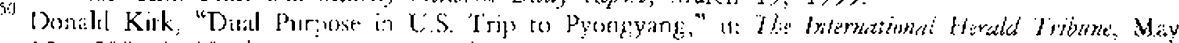

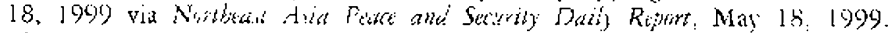

"The Unied States Heuse of Represcratates Committes un International Relatioss, "Statemeat by

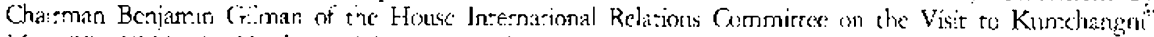

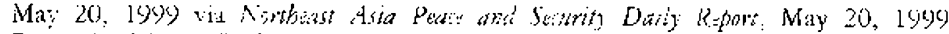

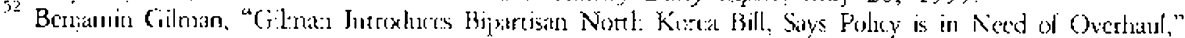

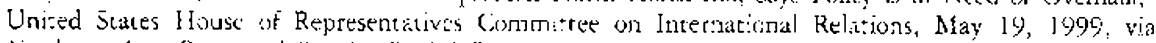

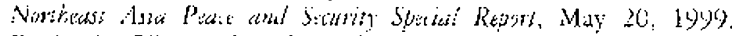

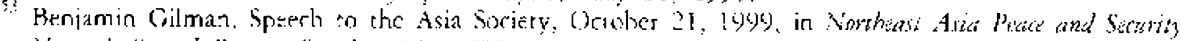

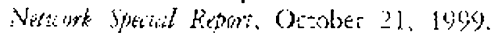

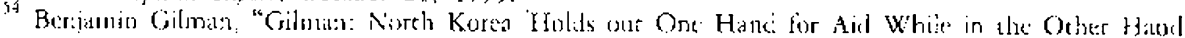

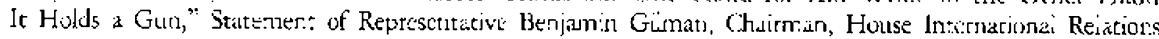

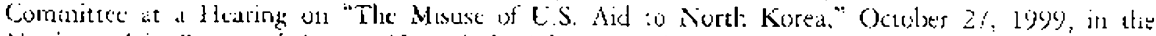

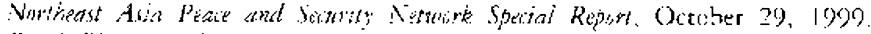

"Carsl Giacornis, "Perry Briets Corgres: Or. North Kotea Repore" Rcuters, Seotember 15, 1999 via

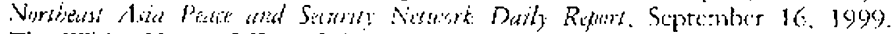

"The White House Office od the Press Secrecary. "Easing Sanctions Agains: North Korea," Septembe:

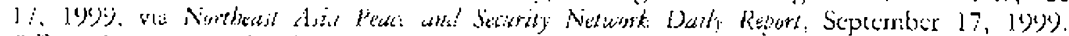

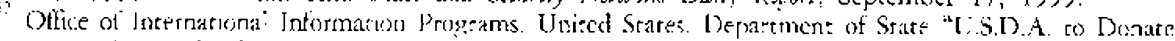

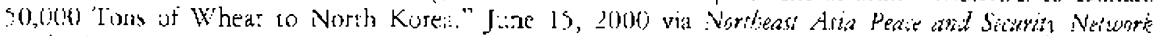
Dail: Report, June 15. 2000).

in John Diamoxd, "For Vorta Karea, U.S. OAfers Carrot, Stick," Chichgo Tribanc, lune 9, 2000 via

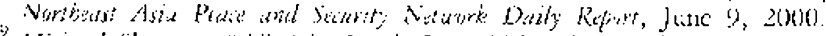

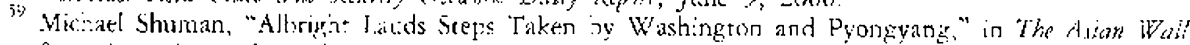

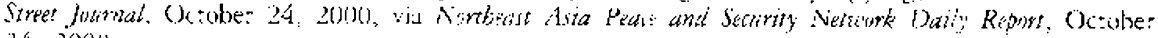
$1.4,2000$

(a) Sec Presiden: Kenneciy's Press Conference Novenber 14, 1963. Jiunes C. Thomson Papers, Far East

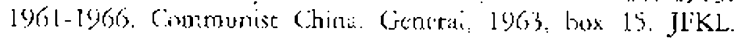

